\title{
Polychlorinated Dibenzo-P-Dioxins and Dibenzofurans (PCDD/F) Measurements in Ambient Air over the Northern Poland
}

\author{
Niemirycz E., Witt M., and Kobusińska M.
}

\begin{abstract}
Polychlorinated dibenzo-p-dioxins and dibenzo furans (PCDD/F), although present in the environment in trace amounts are considered in the context of the global Stockholm Convention on Persistent Organic Pollutants and other scientific committees as extremely hazardous substances belonging to the group of "endocrine disruptors". Examination of their concentration in the air is of particular importance in the regions located on the border of land and sea. $\mathrm{PCDD} / \mathrm{F}$ as a result of atmospheric deposition from land-based sources enter the organisms (fish) in the process of bioaccumulation, as well as aggravate the conditions of coastal tourist areas. This study presents the first measurements of PCDD/F in the ambient air over Gdansk, a town located closely to the beaches of the southern coast of the Baltic Sea. 17 WHO's most toxic PCDD/F congeners from the group of 210 organochlorine compounds have been identified. Congeners proportions are characteristic for municipal incinerators in other European countries. However, the level of the sum of 17 congeners of $\mathrm{PCDD} / \mathrm{F}$ in the air Gdansk is lower $(0.230 \mathrm{pg}$ WHO- TEQ $/ \mathrm{m}^{3}$ ) when compared with other European cities $\left(0.300 \mathrm{pg}\right.$ WHO- TEQ/m $\left./ \mathrm{m}^{3}\right)$. In the summer time, the air over the Gdansk urban background station can be considered as "ecologically clean".
\end{abstract}

Index Terms-Hazardous substances, aerosols, Baltic sea, Poland.

\section{INTRODUCTION}

Polychlorinated dibenzo-p-dioxins and dibenzofurans (PCDD/F) emissions from various sources have raised serious concerns globally because of their toxicological effects and associated adverse health implications. PCDD/F belong to the group of substances influencing the endocrine system by disrupting the secretion of hormones (endocrine disruptors) of humans and other organisms. Due to this fact, the air emissions should be controlled and restricted in case of any significant exceedances from the acceptable level.

As the main sources of emissions are considered waste incineration processes, although scientific studies indicate the existence of many other emission sources, such as chemical industry, metallurgy and municipal combustion. Considerably relevant is emission from non-point sources, due to the fact, that it is remains uncontrolled and its reduction is therefore challenging problem essential to solve.

Manuscript received March 14, 2015; revised May 20, 2015. This research was funded by National Science Centre (grant no. NCN N305 060440).

Niemirycz E., Witt M., and Kobusińska M. are with University of Gdansk, Institute of Oceanography, Department of Marine Chemistry and Environmental Protection, Poland (e-mail: elzbieta.niemirycz@ug.edu.pl, ocemsk@ug.edu.pl, marta.kobusinska@ug.edu.pl).
After emission, these pollutants are transported and diffused through the atmosphere, resulting in subsequent widespread deposition into terrestrial and aquatic ecosystems [1]. Because of public concerns over toxicological effects of $\mathrm{PCDD} / \mathrm{Fs}$, increasingly stringent emission regulations have been enacted in most industrialized countries. According to the Stockholm Convention (2001), many countries have committed themselves to reduce their concentrations in the environment. The atmosphere constitutes a relevant source of $\mathrm{PCDD} / \mathrm{F}$ to the land and marine environment [2], [3]. Dioxins were included in the Convention on Long-Range Transboundary Air Pollution (CLRTAP) list from 1998. Data on concentrations of PCDD/F in the ambient air over the central-east region of Europe are rather limited. Therefore, in 2012 and 2013, PCDD/F in the center of the urban area have been investigated (Tricity, c.a. 750 thousands of residents, polycentric metropolitan center, combined with three cities: Gdansk, Gdynia and Sopot), located near the coast of the Gulf of Gdansk (southern coast of the Baltic Sea) (Fig. 1). The study comprises first measurements of PCDD/F in the ambient air over Gdansk (450 thousands residents) to assess their level of emission and the potential impact on coastal beaches recreation area.

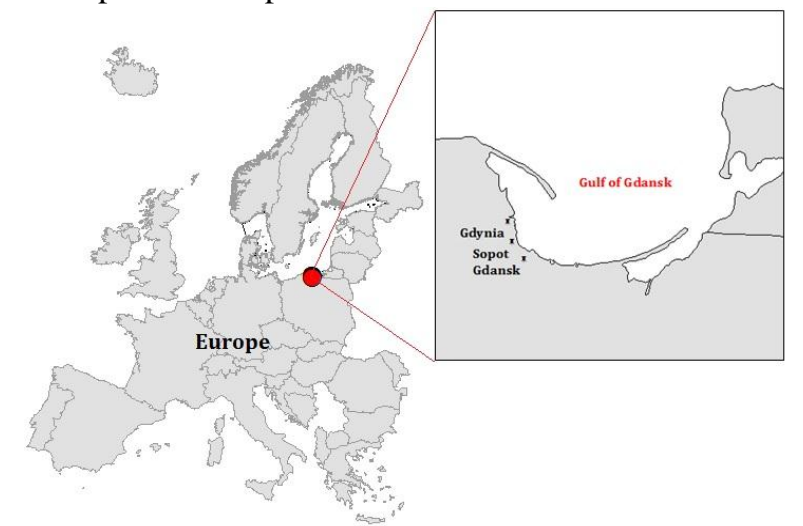

Fig. 1. The map of the study area- the urban background station located in Gdańsk, southern coast of the Baltic Sea, northern Poland, Europe.

\section{MATERIALS AND METHODS}

\section{A. Sampling}

Aerosols PM 10 have been collected by active sampling method (5 sampling) during winter season (December 2012, January 2012 and 2013) and summer (July and August 2012) at station of urban background in the centre of the residential area of Gdansk-Wrzeszcz. The active, high volume air samplers (HVS Digitel) consisting of the quartz filters (Whatman $150 \mathrm{~mm}$ diameter, $450 \mu \mathrm{m}$ thick, $2.2 \mu \mathrm{m}$ 
pore diameter), type QMA has been applied. The results were converted into volume of air passed through the filter while collecting the sample.

A theory of the active air sampling using the similar devices was described further in European Norm PN-EN 12341:2014-07. The sampling chambers were prewashed and solvent -rinsed with acetone prior to installation. An average sampling rate of such device was estimated to 30 $\mathrm{m}^{3} / \mathrm{h}$. The air samples have been collected from 3- 7 days depending on sample which is equal of 2160-5040 $\mathrm{m}^{3}$ of passing air volume on each sample, respectively. The exposed quartz disks were wrapped in two layers of the aluminum foil and transported to the laboratory where they were kept in the freezer at $-18^{\circ} \mathrm{C}$ until analysis.

\section{B. PCDD/F Analysis and Expression of the Results}

The European Norm PN-EN 1948-4+A1:2014-03 (1 -2 -3 and -4) served as the basic methodology for determining PCDD/F. Four parts of the Norm describes the rules of sample collection, extraction and purification as well as identification and quantitative determination of 17 PCDD/F congeners and collection and determination of dioxin-like PCB. According to this Norm the internal standards were added as mix of $17 \mathrm{PCDD} / \mathrm{F}$, this procedure have been described further in our literature [4]. The purified sample was analyzed applying the accepted reference method by high resolution gas chromatography and tandem mass spectrometry GC/MS-MS consistent with European Union Regulation 709/2014 in accredited laboratory of Cracow University of Technology. The results are expressed in $\mathrm{pg} / \mathrm{m}^{3}$. The results provided by laboratory were expressed with the accuracy of $10^{-2} \mathrm{pg} / \mathrm{m}^{3}$, after recalculation by the volume value of the air so the final result is expressed with the accuracy of $10^{-4} \mathrm{pg} / \mathrm{m}^{3}$. Concentrations of PCDD/F are also calculated into pg WHO-TEQ $/ \mathrm{m}^{3}$ (Toxicity Equivalent) using TEF (Toxicity Equivalent Factor) for each analyzed congener in order to compare the obtained values to the established acceptable limits (Table I).

\section{Quality Assurance/Quality Control}

The field blanks consisted of the pre-extracted HVS Digitel disks and were taken at each sampling site according to PN-EN 12341:2014-07. They were extracted and analyzed in the same way as the PCDD/F samples, indicating a minimal contamination during the transport, storage and analysis.

TABLE I: TOXICITY EQUIVALENT FACTORS (TEF) FOR CONGENERS OF PCDD/F ESTABLISHED BY WHO (2005)

\begin{tabular}{|c|c|c|c|}
\hline $\begin{array}{c}\text { Congeners of } \\
\text { PCDD }\end{array}$ & $\begin{array}{c}\text { WHO- } \\
\text { TEF }\end{array}$ & $\begin{array}{c}\text { Congeners of } \\
\text { PCDF }\end{array}$ & $\begin{array}{c}\text { WHO- } \\
\text { TEF }\end{array}$ \\
\hline $2,3,7,8-\mathrm{TCDD}$ & 1 & $2,3,7,8-\mathrm{TCDF}$ & 0.1 \\
\hline $1,2,3,7,8-\mathrm{PCDD}$ & 1 & $2,3,4,7,8-\mathrm{PCDF}$ & 0.3 \\
\hline $1,2,3,4,7,8-\mathrm{HxCDD}$ & 0.1 & $1,2,3,7,8-\mathrm{PCDD}$ & 0.03 \\
\hline $1,2,3,6,7,8-\mathrm{HxCDD}$ & 0.1 & $1,2,3,4,7,8-\mathrm{HxCDF}$ & 0.1 \\
\hline $1,2,3,7,8,9-\mathrm{HxCDD}$ & 0.1 & $1,2,3,6,7,8-\mathrm{HxCDF}$ & 0.1 \\
\hline $\begin{array}{c}1,2,3,4,6,7,8- \\
\text { HpCDD }\end{array}$ & 0.01 & $1,2,3,7,8,9-\mathrm{HxCDF}$ & 0.1 \\
\hline OCDD & 0.0003 & $2,3,4,6,7,8-\mathrm{HxCDF}$ & 0.1 \\
\hline \multirow{2}{*}{} & $\begin{array}{c}1,2,3,4,6,7,8- \\
\text { HpCDF }\end{array}$ & 0.01 \\
\cline { 3 - 4 } & $\begin{array}{c}1,2,3,4,7,8,9- \\
\text { HpCDF }\end{array}$ & 0.01 \\
\cline { 3 - 4 } & & $\mathrm{OCDF}$ & 0.0003 \\
\cline { 3 - 4 }
\end{tabular}

\section{RESULTS AND DISCUSSION}

The high volume, active air sampler used in present study demonstrated a high level of precision based on the replicates. Distribution of ground-boundary wind direction at seaside regional level was north-east direction in winter and west direction. Mean values of temperature (annual mean) at station in Gdansk Wrzeszcz in 2012 was $9.4^{\circ} \mathrm{C}$. The mean value of temperature in July- August 2012 was $19.3^{\circ} \mathrm{C}$ and December - January was $2.1^{\circ} \mathrm{C}$ according to the meteorological data from investigated station provided by ARMAAG [5]. The subject of chemical analysis in presented paper is samples of atmospheric aerosols of fraction below $10 \mu \mathrm{m}-\mathrm{PM} 10$. A contribution of fine fraction PM 2.5 in concentration of PM 10 remains at a comparable level throughout the year. In the summer part PM 2.5 fine dust in the dust PM 10 stands at of PM 2.5/PM $10-0.82$, and in August PM 2.5/PM $10-0.73$, so it seems that changes in concentration of $\mathrm{PCDD} / \mathrm{F}$ are apparently associated with emission during the winter heating season [5]. Because of the strong adsorbing properties of PCDD/F on the surface-active particulate matter, these substances are present in the air mainly adsorbed.

Irrespectively of the season, all PCDD/F congeners have been identified, either of low number of chlorine atoms in the molecule as TeCDD/F and also with a high number of chlorine atoms as $\mathrm{HpCDD} / \mathrm{F}$ and OCDD/F (Table II).

The highest concentrations occurred in the winter, January 2013, and the lowest in summer, July 2012. This larger sorption capacity in winter may indicate higher amount of soot (black) carbon present in the aerosols, enhancing sorption of dioxins to the aerosols [6]. According to the Norm PN-EN 1948-4+A1:2014-03 allowable concentration of emission sources of $\mathrm{PCDD} / \mathrm{F}$ and the air is $0.100 \mathrm{ng}$ WHO-TEQ $/ \mathrm{m}^{3}$ (100 pg WHO-TEQ $\left./ \mathrm{m}^{3}\right)$. According to data from EMEP (European Monitoring and Evaluation Programme) concentrations of PCDD/F in the air over European major cities (more than a million residents) does not exceed $0.300 \mathrm{pg}$ WHO-TEQ $/ \mathrm{m}^{3}$ in winter [7]. The results of the sum of PCDD/F congeners divided by the toxic equivalency factors (TEF, Table I) showed that in December 2013, the sum reached the maximum value of $0.230 \mathrm{pg}$ WHO-TEQ $/ \mathrm{m}^{3}$. In the summer season ranged from 0.006-0.009 pg WHO-TEQ $/ \mathrm{m}^{3}$. These data indicate that air pollution in the winter season in Gdansk is significantly lower in comparison with other European cities [8]. In the summer, the air over the Gdańsk urban background station can be considered as "ecologically clean".

Congeners proportions are characteristic for municipal combustion in other European countries [9]. Several times higher concentrations of the PCDF sum compared with the PCDD sum have been recorded. Alarming phenomenon is the appearance of the significant concentrations, especially in winter, the most toxic forms of TeCDD/F. However, this level is not dangerous for humans and animals. During the heating season, the concentration of congeners hepta and octa chlorinated PCDD/F increases significantly (Fig. 2).

The research carried out in Japan, showed that for people working directly on the municipal combustion furnaces, only hepta chlorinated congeners increased in comparison to the control group [10]. 
TABLE II: CONCENTRATIONS OF PCDD/F CONGENERS IDENTIFIED IN AMBIENT AIR AT THE URBANBACKGROUND STATION IN GDAŃSK, SOUTHERN COAST OF THE BALTIC SEA, NORTHERN POLAND, EUROPE (EXPRESSED IN PG/M ${ }^{3}$ )

\begin{tabular}{|c|c|c|c|c|c|}
\hline Congeners of PCDD/F & $\mathbf{2 8 - 3 1 . 0 1 . 2 0 1 2}$ & $\mathbf{0 2 - 0 8 . 0 7 . 2 0 1 2}$ & $\mathbf{3 0 . 0 7 - 0 2 . 0 8 . 2 0 1 2}$ & $\mathbf{2 4 - 2 6 . 1 2 . 2 0 1 2}$ & $\mathbf{0 7 - 0 9 . 0 1 . 2 0 1 3}$ \\
\hline $2,3,7,8-\mathrm{TeCDD}$ & 0.00097 & 0.00038 & 0.00069 & 0.00435 & 0.00880 \\
\hline $1,2,3,7,8-\mathrm{PeCDD}$ & 0.00451 & 0.00058 & 0.00134 & 0.02130 & 0.03611 \\
\hline $1,2,3,4,7,8-\mathrm{HxCDD}$ & 0.00108 & 0.00009 & 0.00010 & 0.00181 & 0.00310 \\
\hline $1,2,3,6,7,8-\mathrm{HxCDD}$ & 0.00115 & 0.00015 & 0.00042 & 0.00495 & 0.00569 \\
\hline $1,2,3,7,8,9-\mathrm{HxCDD}$ & 0.00104 & 0.00013 & 0.00025 & 0.00449 & 0.00611 \\
\hline $1,2,3,4,6,7,8-\mathrm{HpCDD}$ & 0.00066 & 0.00015 & 0.00025 & 0.00230 & 0.00299 \\
\hline OCDD & 0.00005 & 0.00001 & 0.00001 & 0.00010 & 0.00010 \\
\hline $2,3,7,8-\mathrm{TeCDF}$ & 0.00236 & 0.00026 & 0.00021 & 0.00380 & 0.00537 \\
\hline $1,2,3,7,8-\mathrm{PeCDF}$ & 0.00088 & 0.00010 & 0.00010 & 0.00189 & 0.00293 \\
\hline $2,3,4,7,8-\mathrm{PeCDF}$ & 0.01365 & 0.00125 & 0.00194 & 0.03097 & 0.04722 \\
\hline $1,2,3,4,7,8-\mathrm{HxCDF}$ & 0.00545 & 0.00073 & 0.00088 & 0.01014 & 0.01329 \\
\hline $1,2,3,6,7,8-\mathrm{HxCDF}$ & 0.00434 & 0.00065 & 0.00083 & 0.01000 & 0.01361 \\
\hline $1,2,3,7,8,9-\mathrm{HxCDF}$ & 0.00030 & 0.00004 & 0.00015 & 0.00029 & 0.00134 \\
\hline $2,3,4,6,7,8-\mathrm{HxCDF}$ & 0.00479 & 0.00105 & 0.00116 & 0.01185 & 0.01588 \\
\hline $1,2,3,4,6,7,8-\mathrm{HpCDF}$ & 0.00120 & 0.00074 & 0.00055 & 0.00428 & 0.06453 \\
\hline $1,2,3,4,7,8,9-\mathrm{HpCDF}$ & 0.00031 & 0.00010 & 0.00008 & 0.00044 & 0.00044 \\
\hline OCDF & 0.00002 & 0.00002 & 0.00000 & 0.00006 & 0.00002 \\
\hline Sum $\mathbf{\Sigma} \mathbf{W H O - T E Q}$ & 0.04275 & 0.00643 & 0.00898 & 0.11302 & 0.22754 \\
\hline
\end{tabular}

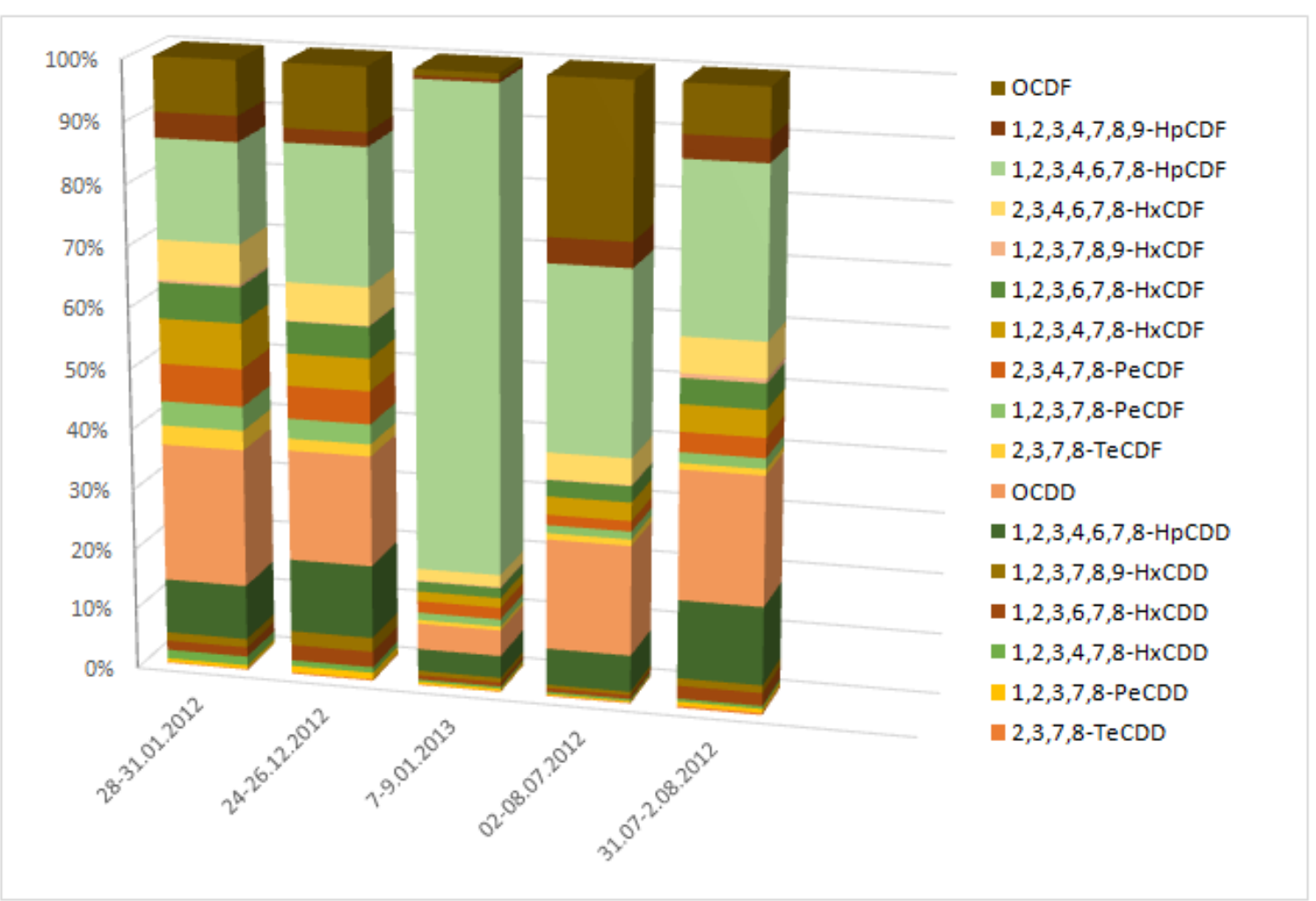

Fig. 2. The percentage contribution of PCDD/F congeners identified in PM 10 aerosols over Gdansk in winter and summer seasons. 


\section{CONCLUSIONS}

In 2012-2013, the analysis of concentration of hazardous polychlorinated dibenzo-p-dioxins and dibenzo furans (PCDD/F), in ambient air of Gdansk, a city located in the coastal zone of the Baltic Sea has been carried. The results obtained in presented paper enable to form the following conclusions:

- The concentrations of PCDD/F in the atmosphere at the level of $0.006 \mathrm{pg}$ WHO-TEQ $/ \mathrm{m}^{3}$ in summer to $0.230 \mathrm{pg}$ $\mathrm{WHO}-\mathrm{TEQ} / \mathrm{m}^{3}$ during the winter season remain at lower level in comparison to other European cities.

- The high PCDD/F levels during the winter season indicate a dominance of non-industrial combustion sources, presuming that there is no seasonal trend in traffic and industrial production.

- The examination of variations of PCDD/F concentrations in the air of the coastal zone are important due to the proved dominance of atmospheric deposition as a source of these substances in the contamination of the Baltic Sea environmental compartments.

- Reduction of emission from non-point sources appears to be the most relevant issue, considering that industrial emission has decreased over the last decades.

\section{ACKNOLEDGMENTS}

Msc. Ryszard Potrykus from Regional Inspectorate of Environmental Protection in Gdańsk is greatly acknowledged for collection of air samples.

\section{REFERENCES}

[1] J. B. Wang, G. P. Chang-Chien, W. Y. Lin, J. H. Yeh, and C. H. Hung, "A seasonality study of polychlorinated dibezno-p-dioxins and dibenzofurans in ambient air in Kaohsiung (Taiwan) clustered with metallurgical industries," Journal of Hazardous Materials, vol. 162, pp. 103-110, 2009.

[2] T. Chen, X. Li, J. Yan, S. Lu, and K. Cen, "Distribution of polychlorinated dibezno-p-dioxins and dibenzofurans in ambient air of different regions in China," Atmospheric Environment, vol. 45, pp. 6567-6575, 2011.

[3] R. E. Alocock, A. J. Sweetman, and K. C. Jones, "A congenerspecific PCDD/F emissions inventory for the UK: do current estimates account for the measures atmospheric burden?' Chemosphere, vol. 43, pp. 183-194, 2001.

[4] E. Niemirycz and D. Jankowska, "Concentration and profiles of $\mathrm{PCDD} / \mathrm{Fs}$ in sediments of major polish rivers and the Gdansk Basin Baltic Sea," Chemosphere, vol. 85, pp. 525-532, 2011.

[5] Foundation Regional Air Quality Monitoring Agency Agglomeration of Gdansk, "The state of atmospheric air pollution in the agglomeration of Gdansk and Tczew in 2013," ARMAAG Report, p. $131,2013$.

[6] G. Cornelissen, K. Wiberg, D. Broman, H. P. H. Arp, and Y. Persson, "Freely dissolved concentrations and sediment-water activity ratios of PCDD/Fs and PCBs in the open Baltic Sea," Environmental Science \& Technology, vol. 42, pp. 8733-8739, 2008.
[7] U. Quass, M. W. Fermann, and G. Broker, "Steps towards a European Dioxin Emission Inventory," Chemosphere, vol. 40, pp. 1125-1129, 2000.

[8] K. Kuhlbusch, U. Quass, M. Koch, H. Fissan, P. Bruckmann, and U. Pfeffer, "PM10 source apportionment at three urban back ground sites In the western Ruhr-area," Journal of Aerosol Science, vol. 35, no. 1, pp. 79-9, 2004.

[9] T. Krauss, P. Krauss, and H. Hagenmaier, "Formation of PCDD/PCDF during composting?" Chemosphere, vol. 28, pp. 155158,1994

[10] S. Kumagai, S. Koda, T. Miyakita, and M. Ueno, "Polychlorinated Dibenzo p-dioxin and dibenzofuran concentrations in serum samples of workers at intermittently burning municipal waste incinerators in Japan," Journal Occupational Environmental Medicine, vol. 59, pp. 362-368, 2000.

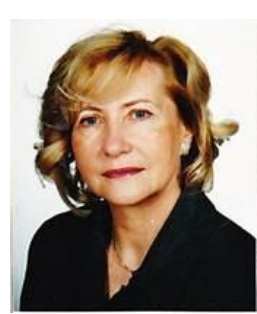

Niemirycz E. is a professor at Institute of Oceanography at Department of Marine Chemistry and Environmental Protection of Gdansk University. Her main research interests are discharges of pollutants to the marine environment, anthropogenic and natural emissions of pollutants, methods of pollution abatement, harmful substances in environment, legal aspects related to the Stockholm Convention, as well as coastal zone research. Professor Niemirycz is an author of numerous publications in peer-reviewed journals, books or chapters in books and expert evaluations, as well as technical reports. She has been an active teacher, supervising numerous masters and one doctoral thesis and national and international grant applications. She has also participated in many local and global conferences. Professor Niemirycz is coauthor of National Implementation Program for the Stockholm Convention. She received in 2009 Minister of the Environment Award for lifetime research in the field of environmental protection and its resources. From 2009 she has been Rector's Representative for the Cooperation with Ministry of the Environment. Currently she is a member of the Council of the Baltic Sea States.

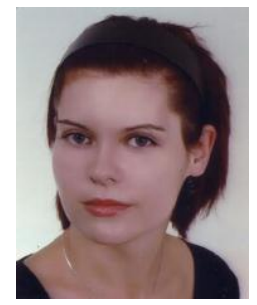

Witt M. is a PhD student at University of Gdansk (Poland), Institute of Oceanography, Department of Marine Chemistry and Environmental Protection. Her main scientific interests include identification of sources of dioxins and dioxin-like substances based on congener profiles pattern, applying advanced statistical methods.

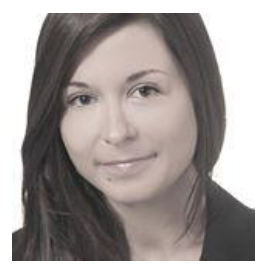

Kobusińska M. is a PhD student at University of Gdansk (Poland), Institute of Oceanography, Department of Marine Chemistry and Environmental Protection. Her main scientific interests comprise distribution of organic pollutants, particularly dioxins and their precursors in the environment as well as processes marine trophic chain. of bioaccumulation and biomagnification in 